\title{
ANALISIS PENGARUH ETNISITAS DALAM PENGISIAN JABATAN STRUKTURAL DI PEMERINTAH KABUPATEN MUARO JAMBI: PASCA PILKADA 2017
}

\author{
Makmun Wahid ${ }^{1}$, Haryadi $^{2}$ \\ ${ }^{1}$ Program Studi Ilmu Pemerintahan, Fakultas Ilmu Sosial dan Ilmu Politik, Universitas Jambi, Indonesia \\ makmun.wahid90@yahoo.com \\ ${ }^{2}$ Program Studi Ilmu Pemerintahan, Fakultas Ilmu Sosial dan Ilmu Politik, Universitas Jambi, Indonesia \\ haryadifh@yahoo.co.id
}

\begin{abstract}
Abstrak
Bermainnya politik etnis Jawa dalam perebutan jabatan politik dan birokrasi di Kabupaten Muaro Jambi melahirkan interaksi negatif bagi etnis Jawa dan etnis-etnis lain di Kabupaten Muaro Jambi. Apa yang dilakukan oleh etnis Jawa merupakan upaya mereka untuk menunjukkan dominasinya terhadap etnis lain di Kabupaten Muaro Jambi. Dimana sebelumnya konsep putra daerah menjadi wacana bagi proses pengisian jabatan-jabatan tersebut. Penelitian ini menggunakan metode penelitian kualitatif, dengan pendekatan studi kasus dan teknik analisis data triangulasi. Dari metode yang digunakan tersebut diperoleh gambaran bagaimana kebangkitan politik etnis Jawa memberikan jalan bagi mereka untuk mendominasi jabatan politik dan jabatan birokrasi. Selain itu, pola dukungan pun akan terfragmentasi atas kesamaan identitas semata, terutama terkait kesamaan etnis. Tidak netralnya para birokrat dalam Pilkada menunjukkan bahwa partai politik di Indonesia tidak melembaga dengan baik. Tidak heran, jika setelah Pilkada usai, hal itu memberikan dampak secara tidak langsung pada mekanisme rotasi, mutasi dan promosi jabatan-jabatan struktural di lingkup pemerintahan Kabupaten Muaro Jambi. Dimana penempatan orang yang dilakukan di dalam tubuh birokrasi akan didominasi oleh pengaruh etnis Jawa, yang kemudian pelan-pelan 'menyingkirkan' etnis lainnya. Jelasnya, mekanisme seperti itu cenderung lebih mengedepankan pendekatan patron klien ketimbang mengutamakan kinerja dari individu pejabat. Tulisan ini mengisyaratkan perlunya intervensi secara regulatif maupun tekhnis agar mekanisme pengisian jabatan publik di dalam birokrasi pasca Pilkada di Indonesia ke depan dapat menghasilkan elit-elit pemerintahan yang lebih berkualitas dan berintegritas. Penggunaan media digital baru menjadi tawaran bagi pembaharuan paradigma Birokrasi Pasca Pilkada.

Kata kunci: Birokrasi, Etnisitas, Media Digital Baru.
\end{abstract}

\begin{abstract}
The playing of Javanese ethnic politics in the struggle for political office and bureaucracy in Muaro Jambi District gave rise to negative interactions for Javanese ethnicity and other ethnicities in Muaro Jambi Regency. What is done by Javanese is their attempt to show their dominance over other ethnic groups in Muaro Jambi Regency. Where previously the concept of the son of the region became a discourse for the process of filling these positions. This study uses qualitative research methods, with a case study approach and triangulation data analysis techniques. From the method used a description of how the rise of Javanese ethnic politics provided a way for them to dominate political office and especially for bureaucratic office. In addition, the pattern of support will be fragmented for the same identity, especially related to ethnic similarities. The neutrality of the bureaucrats in the elections shows that political parties in Indonesia do not institutionalize well. Not surprisingly, after the election is over, it has an indirect impact on the mechanism of rotation, mutation and promotion of structural positions in the Muaro Jambi District government. Where the placement of people carried out in the body of the bureaucracy will be dominated by Javanese ethnic influences, which then slowly 'get rid of' other ethnicities. Clearly, such a mechanism tends to prioritize the patron client approach rather than prioritizing the performance of individual officials. This paper suggests the need for interventions both regulative and technical so that the mechanism for filling public positions in the post-election bureaucracy in Indonesia in the future can produce government elites
\end{abstract}


that are more qualified and with integrity. The use of new digital media is an offer for renewing the paradigm of the Post-Election Bureaucracy.

Keywords: Bureaucracy, ethnicity, new digital media.

\section{PENDAHULUAN}

Studi ini bermaksud untuk melihat bagaimana pengaruh etnisistas dalam pengisian jabatan struktural pada jajaran birokrasi pemerintah daerah Kabupaten Muaro Jambi pasca Pilkada 2017. Selain itu, studi ini juga secara bersamaan akan menghasilkan dan memberikan gambaran umum strategi seperti apa yang dapat mewujudkan netralitas dan profesionalisme Birokrasi setelah Pilkada berlangsung.

Persoalan kebangkitan identitas etnis dan birokrasi merupakan masalah yang paling ramai dibicarakan di negeri ini, di samping integrasi nasional, korupsi, partai politik, dan kohesi nasional. Apalagi bila hal itu dikaitkan mekanisme penggantian dan pengisian jabatan publik yang terjadi berbarengan dengan pelaksanaan Pilkada telah menimbulkan sejumlah konsekuensi yang hasilnya sering malah tidak diharapkan; penyimpangan dan juga ekses. Akibatnya, kian banyak lembaga negara yang terus mewacanakan beberapa perubahan. Tentu saja, yang paling menguat adalah mengembalikan proses pemilihan kepala daerah ke tangan DPRD (Media Indonesia, 2018).

Peralihan dari era Orde Baru ke era Reformasi telah mengubah pandangan masyarakat Indonesia tentang identitas etnis dan birokrasi. Kebangkitan identitas dalam birokrasi di era Reformasi dimaknai dengan munculnya identitas kedaerahan dan kesadaran politik baru untuk merestrukturisasi birokrasi atas dasar primordial etnis atau kesukuan. Dalam ranah sosial budaya, kebangkitan identitas tercermin dari upaya memasukan nilai-nilai keetnisan ke dalam peraturan daerah, pemekaran wilayah berbasis etnis dan perjuangan untuk mendapatkan otonomi khusus. Akibatnya, Reformasi yang awalnya tampak sebagai rezim yang solid dan tak tergoyahkan ternyata kini menjadi negara yang rapuh, ketika politik identitas etnis, keagamaan dan kedaerahaan menjadi lebih dominan (Nordholt, Schulte dan Klinken, 2007: 4). Bahkan disinyalir oleh banyak peneliti bahwa gerakan politik etnis kian banyak dipakai oleh para politisi di tingkat lokal untuk mendapatkan kekuasaan.

Yang menarik adalah di tengah terjadinya konflik etnis dan golongan seperti yang terjadi di Papua, Ambon, Dayak, Madura, dan lain sebagainya. Dengan situasai dan kondisi sosial politik yang hampir sama, hal tersebut tidak terjadi di Kabupaten Muaro Jambi yang 
resistensi kerusuhan etnisnya sangat kecil. Berdasarkan jumlah penduduk dilihat dari suku, maka yang terbanyak adalah suku melayu (35.6\%), suku Jawa (22.2 \%), Suku Suku Minang (9.3\%), Suku Batak (8.1\%), Suku Bugis (2.2\%), Suku Banjar (0.7\%), dan suku-suku lain $(21,9 \%)$. Komunitas etnis-etnis tersebut terlibat dalam pergumulan kontestasi di proses politik Pilkada Muaro Jambi, kontak budaya, konflik atau persaingan ekonomi, akomodasi, asimilasi, adaptasi, akulturasi, negosiasi dan kontestasi dalam interaksi sosial mereka. Proses interaksi politik etnis inilah yang kemudian mempengaruhi perubahan identitas baik politik, agama dan budaya.

Pembangunan politik dan budaya etnis etnis Jawa yang merupakan etnis terbesar kedua di Muaro Jambi, telah membentuk identitas baru yang merupakan sintesis dari proses panjang interaksi sosial. Dengan begitu, model pola interaksi etnis dalam pemilihan kepala daerah patut kita simak ketika sebagain besar wilayah di Indonesia terjadi kerusuhan etnis dalam pemilihan kepala daerah seperti yang terjadi di provinsi-provinsi pada bagian Indonesia timur. Hal ini menandakan bahwa identitas etnis dalam kegiatan politik di ranah lokal sangat kuat, namun berbeda di Muaro Jambi yang menunjukkan model komunikasi antar etnis yang justru tetap harmonis. Ditandai tidak adanya terjadi kerusuhan etnis di kabupaten yang merupakan salah satu dari daerah pemekaran di Provinsi Jambi ini. Jikapun ada gesekan yang terkait etnisitas, maka itu hanya persoalan eksistensi etnis dalam panggung Pilkada. Serta adanya tekanan terhadap birokrasi yang disebabkan oleh politik etnis yang terpelihara.

Berdasarkan latar belakang di atas, sulit rasanya kemudian menyajikan sebuah ide yang benar-benar original, atau dalam hal ini memberikan sebuah pandangan dan temuan baru mengenai studi tentang birokrasi di Indonesia. Sebabnya, hasil penelusuran terhadap penelitian terdahulu menunjukkan bahwa sungguh sudah sangat lengkap memberikan referensi terhadap studi tentang birokrasi. Mulai dari kritik atas konsep birokrasi, politisasi dalam tubuh birokrasi yang menyangkut etnisitas, intervensi serta tuntutan netralitas, dan bahkan sampai tataran bagaimana memberikan usulan serta konsep baru tentang birokrasi yang seharusnya dijalankan dalam sistem pemerintahan di Indonesia. Namun, penelitian ini nantinya diharapkan tidak sekedar untuk melengkapi studi yang telah ada. Studi ini akan berfokus pada bagaimana politisasi birokrasi dan pengangkatan pejabat struktural di Kabupaten Muaro Jambi lebih mengedepankan kedekatan emosional dan subyektifitas berdasarkan kesamaan etnis. 
Berangkat dari kondisi itu, penelitian ini menjadi penting dilakukan terutama untuk mencari faktor penyebab kegagalan birokrasi dalam menjamin prinsip netralitas dan profesionalisme. Pelacakan terhadap politisasi etnis dalam birokrasi sangat diperlukan, mengingat reformasi birokrasi saat ini sedang getol-getolnya hendak ditegakkan.

\section{METODELOGI}

Penelitian ini menggunakan metode penelitian kualitatif, dengan pendekatan studi kasus dan mengelaborasi berbagai macam literatur baik berupa buku, jurnal, maupun literatur yang relevan dengan tema tulisan. Metode ini dipilih karena ingin memadukan hasil temuan bertema sama. Hal tersebut ditujukan untuk mengkonfirmasi penelitian terdahulu, sekaligus mencari unsur kebaruan dalam penelitian selanjutnya.

\section{PEMBAHASAN}

\section{ETNISITAS YANG MENGAKAR}

Koentjaraningtat dalam Liliweri (2005: 10) menjelaskan etnik sebagai kelompok sosial atau kesatuan hidup manusia yang memiliki sebuah sistem interaksi, sistem norma yang mengatur interaksi tersebut, adanya kontinuitas rasa identitas yang mempersatukan semua anggotanya serta memiliki sistem kepemimpinan sendiri.

Dalam konsep etnik di dalamnya juga beberapa konsep lain yang berkaitan dengan makna etnik itu sendiri. Semisal contoh konsep etnisitas yang berkaitan langsung dengan penelitian ini. Etnisitas (ethnicity) merupakan konsep yang menjelasakan tentang keberadaan suatu kelompok yang berdasarkan kebudayaan yang mereka miliki dari warisi dari generasi yang sebelumnya. Perbedaannya dengan ras pada dasarnya berdasarkan bahwasanya etnisitas merupakan proses pertukaran kebiasaan berperilaku dan berkebudayaan yang dijalankan secara turun temurun. Dimana identitas kelompok tersebut berdasarkan pada kesamaan karakteristik bahasa, kebudayaan, sejarah dan asal-usul geografis. Pertukaran kebudayaan yang berbasis pada bahasa, agama, dan kebangsaan inilah yang kemudian selalu menghubungkan keyakinan yang ‘berlebihan’ dengan keberadaan kelompok lain.

Karakteristik yang melekat pada satu kelompok etnis adalah tumbuhnya perasaan dalam satu komunitas (sence of community) di antara para anggotanya. Perasaan tersebut menimbulkan kesadaran akan hubungan yang kuat. Selain itu, tumbuh pula perasaan “kekitaan” pada diri anggotanya sehingga muncul lah rasa kekerabatan yang kuat. 
Menurut Abdillah (2002: 76) dalam perkembangannya ada tiga pendekatan dalam teori atau konsep dari etnisitas. Pertama, Primordialis. Kedua, Konstruktifis dan Ketiga, Instrumentalis. Pendekatan ketiga inilah yang kemudian dianggap paling relevan dalam menelaah kasus demi kasus di penelitian ini. Para penganut paham instrumentalis menempatkan etisitas sebagai sesuatu kekuatan sosial, politik, budaya bagi bermacam-macam kepentingan dan beragam status group. Etnisitas dalam pandangan instrumentalis dilihat dari dua versi, yaitu:

1. Versi pertama berfokus pada kompetisi antar elit untuk memperoleh sumber daya dan usaha memanipulasi simbol untuk mendapatkan dukungan massa dan meraih tujuan politik yang hendak dicapai elit (Brass, 1991; Cohen, 1974)

2. Versi kedua berfokus pada strategi elit untuk memaksimalkan pilihan-pilihan rasional dalam given situation. Tujuan elit adalah meraih kekuasaan, status; untuk itu, ia bergabung dalam komunitas, baik komunitas etnis maupun komunitas nasional dengan harapan komunitas tersebut akan menjamin tercapainya tujuan, baik dengan mempengaruhi Negara atau dalam situasi tertentu melalui pemisahan diri (Banton, 1983, 1994; Hecter, 1986, 1992).

Kemunculan politik etnis semacam ini biasanya diawali oleh tumbuhnya kesadaran yang mengidentikkan mereka ke dalam suatu golongan atau kelompok etnis tertentu. Kesadaran ini yang kemudian memunculkan solidaritas kekelompokan dan kebangsaan. Pada wacana politik kontemporer Abdillah (2002: 19) menyebutkan bahwa biasanya kelompok etnis bertujuan lebih pada penerimaan keberadaan mereka dan kemajuan bagi kelompok tersebut. Politik identitas etnis dalam perkembangannya tidak hanya menampilkan diri dalam wacana politik kebudayaan saja, tapi sudah mulai mengarah pada upaya pengakuan dan penguasaan sumber daya politik, sosial, ekonomi sebagai idengenues people.

\section{POLITISASI BIROKRASI}

Pemaknaan terhadap birokrasi sebagai institusi atau instrumen pelayanan publik, tentu merupakan pemaknaan ideal. Namun pemaknaan ideal terhadap fungsi pelayanan publik yang diperankan oleh birokrasi yang rasional, pada kenyataanya tidak sepenuhnya mampu menjelaskan orientasi birokrasi di indonesia. Perjalanan panjang sejarah birokrasi Indonesia selalu membuktikan adanya dominasi aspek politis di bawah hirarki dan regulasi negara. 
Institusi birokrasi yang banyak dimuati oleh kepentingan-kepentingan politik atau bahkan didominasi membuat birokrasi yang semula mempunyai misi utama melayani publik akan cendrung berbelok arah. Hal ini akibat orientasi pelayanan publik yang seharusnya dijalankan, telah bergeser ke arah orientasi yang sifatnya politis. Dalam situasi seperti ini, ada kecendrungan besar birokrasi tidak akrab lagi dengan aspirasi dan kepentingan masyarakat. Ada kemungkinan mereka enggan berurusan dengan keluhan masyarakat, karena yang demikian tidak menguntungkan birokrasi, baik dari sisi material maupun politis. Tjokrowinoto (2001: 113) mengatakan performa birokrasi yang kental dengan aspek-aspek seperti inilah yang pada gilirannya melahirkan stigma Politisasi Birokrasi.

Di dalam teori liberal dimungkinkan adanya pencampuran antara jabatan politik dengan birokrasi. Sebagaimana dikatakan oleh Carino dalam Thoha (2002: 153) bahwa, birokrasi bukan hanya didominasi oleh para birokrat saja, tetapi ada bagian-bagian tertentu yang diduduki oleh pejabat politik. Itu sebabnya, secara umum dapat dikatakan birokrasi kita saat ini diwarnai oleh intervensi kekuatan politik kepala daerah yang berkuasa. Pada saat ini, birokrasi mengalami proses politisasi, mulai dari struktur sampai dengan kulturnya. Tak ada profesionalisma dan rasionalitas, malahan menurut Djumiarti (2010: 71) wajah birokrasi saat ini adalah feodal dan irasional.

Politisasi birokrasi yang dominan di masa orde baru, pada hakekatnya didasari oleh ketakutan penguasa akan hilangnya kepercayaan masyarakat terhadap pemerintah. Dalam konteks ini politisasi birokrasi cendrung diartikan sebagai upaya pemerintah untuk menciptakan kekuatan birokrasi yang mampu memperkuat basis perekonomian penguasa agar bisa efektif mengendalikan warga negara. Tjokrowinoto (2001:117) bahkan mengatakan bahwa, kondisi seperti itu menciptakan birokrasi yang semestinya rasional menjadi irasional, dibuktikan dari indikator sebagai berikut:

1. Birokrasi bekerja bukan untuk melayani kepentingan masyarakat, tetapi ditujukan untuk melayani kepentingan penguasa dan pemilik modal.

2. Orientasi pelayanan publik telah dibelokkan menjadi alat kontrol bagi pelaksanaan kebijakan-kebijakan negara.

3. Birokrasi yang seharusnya netral, tetapi justru berbalik berpihak pada partai politik.

Dengan demikian,wajar bila bahwa kepentingan politik tertentu telah diwakili secara mantap oleh birokrasi, di samping birokrasi yang kini justru enggan melepaskan diri dari 
hegemoni kekuatan politik, di sisi yang lain kontrol masyarakat terkait hal ini sangatlah lemah.

\section{JAWA SEBAGAI SIMPUL KEMENANGAN DALAM PILKADA MUARO JAMBI}

Masyarakat Jawa di Kabupaten Muaro Jambi tidak saja merupakan etnis mayoritas, tetapi juga menjadi rujukan sosial-budaya bagi masyarakat setempat. Sebagai etnis mayoritas, etnis yang datang ke kabupaten ini bahkan menyesuaikan adat istiadat dengan kebudayaan Jawa. Seperti, cara berkomunikasi termasuk bahasa yang digunakan, gaya hidup sehari-hari dan sebagainya.

Sistem kekerabatan dan lokalitas cenderung diwarnai oleh tradisi-tradisi etnis Jawa. Unsur-unsur budaya baru yang diserap dari kehidupan masyarakat setempat segera menjadi bagian penting bagi masyarakat Melayu, Minang, Batak serta etnis lain di kabupaten tersebut. Semakin lama mereka tinggal dan bergaul dalam masyarakat yang didiami etnis Jawa maka akan semakin mudah pula bagi mereka untuk menyerap unsur-unsur budaya masyarakat Jawa tersebut. Semisal, orang-orang Banjar, Minang atau Batak yang sudah tinggal di kawasan masyarakat Jawa sejak lama dan tidak pernah lagi kembali ke tanah kelahirannya, sudah menjadi seperti orang-orang Jawa yang kehidupan sosial-kulturalnya merupakan bagian dari etnis Jawa.

Dominasi kultural Jawa di Kabupaten Muaro Jambi inilah yang kemudian membuat gagasan putra daerah dalam proses politik lokal akan terlihat memudar. Bayangan putra daerah dalam kontestasi Pilkada di Muaro Jambi agaknya tidak dapat disederhanakan dari persoalan eksistensi etnis penduduk asli, apalagi persoalan perlawanan terhadap keberadaan penduduk pendatang.

Kabupaten Muaro Jambi mungkin merupakan salah satu dari banyak kabupaten di republik ini di mana cukup banyak warga etnis Jawa yang mencoba keluar dari tardisi masa silam dan merangsek masuk ke ranah politik praktis entah pada tataran lembaga pemerintahan paling bawah hingga paling tinggi. Dengan melihat realitas ini, kabupaten Muaro Jambi menampilkan wajah yang berbeda dibandingkan kabupaten-kabupaten lain di Provinsi Jambi. Pada tabel di bawah ini terlihat bahwa semua pasangan calon memiliki latarbelakang etnis Jawa. 
Tabel 1 Hasil Perolehan Suara Pilkada Muaro Jambi 2017

\begin{tabular}{|l|c|c|}
\hline \multicolumn{1}{|c|}{ Pasangan Calon Bupati dan Wakil Bupati } & Etnis & Perolehan Suara \\
\hline 1. Abun Yani, SH. - Suharyanto, SH. & Melayu-Jawa & 8.558 \\
\hline 2. Agustian Mahir, SH. - Suswiyanto. & Melayu-Jawa & 43.632 \\
\hline 3. Hj. Masnah, SE. - Bambang Bayu Suseno SP.MM. & Melayu-Jawa & 76.825 \\
\hline $\begin{array}{l}\text { 4. H. Ivan Wirata, ST, MM, MT. - H. Dodi Sularso, } \\
\text { SH. }\end{array}$ & Minang-Jawa & 62.627 \\
\hline
\end{tabular}

Sumber: Keputusan KPU Kabupaten Muaro Jambi tentang Penetapan Hasil Perolehan Suara Pilkada Muaro Jambi 2017

Data tersebut menunjukkan bahwa satu hal yang menonjol di Kabupaten Muaro Jambi adalah kekuatan modal sosial etnis Jawa dalam Pilkada. Politk etnis Jawa menempatkan keturunan pendatang (Jawa) sebagai elit/pemimpin yang memiliki akar masa yang sangat kuat dan mengontrol isu-isu publik dalam penyelenggraan pemerintahan. Hubungan kekerabatan Jawa hingga saat ini memberikan keuntungan politis dalam mempengaruhi isu-isu publik dan demokrasi di ranah lokal. Hal ini terlihat dari menguatnya kedudukan orang-orang Jawa di tanah rantau. Hubungan kekerabatan yang kuat tersebut terukur dalam pengakuan hampir seluruh pasangan calon terhadap pentingnya pengaruh pemilih Jawa dalam penentuan kemenangan di kontestasi Pilkada Muaro Jambi (Jambi Ekspres, 2016).

Hal ini bukan saja sekedar pernyataan, tapi hingga sekarang dapat dibuktikan dengan menguatnya pengaruh kultural Jawa melalui jargon "penak wong dewe" yang masih terjaga dan terpelihara. Itu artinya, simbol kejawaan mempunyai daya magnet tidak hanya dalam dinamika sosial kemasyarakatan, tetapi juga hingga ke arena politik lokal. Jelasnya, kedatangan warga Jawa pada awal tahun 1980-an di Muaro Jambi selain memisahkan mereka dengan keluarga di Jawa ternyata juga menandai bentuk kekeluargaan baru di tanah Sumatera terutama Muaro Jambi yaitu ikatan persaudaraan sesama etnis Jawa. Bagi mereka yang kini bersama menjadi pendatang, ikatan sejarah telah menjadikan mereka lebih dekat bahkan melebihi ikatan darah dan ini merupakan modal sosial penting yang mereka miliki karena menjadikan mereka komunitas yang solid dengan berbagai kegiatan bersama yang terus mereka jaga seperti gotong royong, kenduri, pengajian, berkesenian, berolah raga, dan kegiatan agama lainnya.

Dari sudut pandang ini, para elit birokrat mengembangkan sikap dan menyatu dalam rangkaian kegiatan tersebut. Salah satu basis argumentasi penting yang menjelaskan bahwa pola patron klien antara pejabat birokrat dan warga Jawa begitu mengikat. Hal ini selaras sebagaimana diungkap oleh banyak ilmuwan politik (Dwiyanto, 2002, 2003; Thoha, 2002). 
Para pemimpin seperti kepala dinas, kepala kantor dan camat karena yang mengangkat adalah bupati maka posisi tergantung padanya. Bupati terpilih jelas sengaja mencari orang-orang yang dekat dengan dirinya agar bisi didukung secara total. Ia membangun relasi simbiosis mutualisme. Kepala daerah ingin memperoleh dukungan sedangkan para birokrat ingin memperoleh jabatan atau kedudukan. Berikut hasil penggalian data, tujuan dan kepentingan secara umum dari masing-masing aktor terhadap mekanisme pengisian jabatan struktural di Kabupaten Muaro Jambi dapat dilihat dalam tabel berikut ini:

Tabel 2 Tujuan dan Kepentingan Masing-Masing Aktor terhadap Mekanisme Pengisian Jabatan Struktural Pasca Pilkada

\begin{tabular}{|c|c|c|}
\hline Aktor & Tujuan & Kepentingan \\
\hline $\begin{array}{l}\text { Calon Kepala } \\
\text { Daerah }\end{array}$ & $\begin{array}{l}\text { Masyarakat etnis Jawa dapat } \\
\text { mengetahui dan sadar akan kedekatan } \\
\text { dan kepeduliannya dengan orang Jawa }\end{array}$ & $\begin{array}{l}\text { Dapat dipilih dalam Pilkada } \\
\text { Muaro Jambi }\end{array}$ \\
\hline Birokrat & $\begin{array}{l}\text { Calon kepala daerah dapat percaya } \\
\text { hubungan kekerbatan yang kuat dan } \\
\text { solid antara dirinya dengan massa } \\
\text { Etnis Jawa }\end{array}$ & $\begin{array}{l}\text { Memperoleh jabatan atau } \\
\text { kedudukan }\end{array}$ \\
\hline $\begin{array}{l}\text { Tokoh } \\
\text { Masyarakat dan } \\
\text { Masyarakat Jawa }\end{array}$ & $\begin{array}{l}\text { Dominan dalam penentuan calon } \\
\text { kepala daerah terpilih }\end{array}$ & $\begin{array}{l}\text { Kebijakan yang berpihak } \\
\text { terhadap kepentingan etnis Jawa }\end{array}$ \\
\hline
\end{tabular}

Sumber: Diolah dari hasil wawancara dengan informan dan berbagai data sekunder

Hal ini menunjukkan bahwa dalam peta politik Muaro Jambi, mereka yang memiliki modal sosial ini akhirnya menjadi calon pemilih potensial di mata setiap kandidat yang bertarung dalam pemilihan umum karena akan memberikan sumbangan suara yang signifikan bagi kandidat. Etnis Jawa adalah target pemilih yang diincar oleh keempat pasangan kandidat karena dinilai sebagai komunitas yang solid dan setia. Termasuk strategi menggandeng figur Jawa menjadi bukti dominannya politk etnis Jawa dalam Pilkada Muaro Jambi. Selain itu, dengan modal ekonomi dan sosial yang dimiliki para elt birokrat dianggap mampu menggerakkan massa pemilih untuk mendukung salah satu pasangan.

Secara prinsip, hasil pengamatan dan observasi mendalam terhadap karakteristik masyarakat Jawa, dengan pola politik tradisional yang masih diterapkan maka wajar jika dalam kegiatan politik, mereka cenderung akan memilih calon atau kandidat yang memberikan perhatian dan perlindungan bagi posisi mereka di Muaro Jambi, hal ini terutama 
dipengaruhi oleh cerita suram mereka selama mereka menjadi buruh kasar seperti petani karet dan sawit.

Terhadap berbagai penjelasan mengenai ekspresi politik orang Jawa tersebut, bisa dikatakan bahwa praktik politik etnisitas dalam demokrasi modern di Muaro Jambi yang demikian, menunjukkan terjadinya perebutan pilar kekuasaan birokrasi melalui Pilkada. Sebagai pusat aktifitas pemerintahan lokal, Muaro Jambi menjadi aktualisasi eksistensi etnis Jawa dalam meraih kekuasaan yang diawali dengan proses kandidasi paket Bupati/Wakil Bupati/Wakil Bupati. Penanda lainnya adalah mobilisasi massa melalui organisasi gerakan yang juga memunculkan basis etnis, yakni Wisnu Murti.

Di sisi lain, keterlibatan tokoh Jawa dan Birokrat Jawa jelas mempengaruhi signifikansi perolehan suara di Pilkada Muaro Jambi yang lalu. Hal ini menandakan adanya identitas etnis yang dikonstruksi sedemikian rupa untuk kepentingan elit. Etnis menjadi aset politik bagi birokrat dan calon kepala daerah dalam berbagai bentuk manifestasi sentimen primordial. Struktur relasi sosial terbentuk dari dinamika politik macam ini, tidak heran menghadirkan sebuah pemerintahan yang berbau nepotisme. Hal ini terukur dalam berbagai praktik formal, misalnya rekruitmen dan penempatan pada jabatan struktural yang mempertontonkan bagaimana postur birokrasi berbasis etnis. Bertumpu pada argumen di atas, perlu ditekankan kembali bahwa cara pandang etnis jawa dalam proses politik lokal telah menguatkan posisi etnis mereka sebagai simpul dari menang tidaknya pasangan calon tertentu dalam Pilkada di Muaro Jambi.

\section{MEWUJUDKAN TRANSPARANSI DALAM PENGISIAN JABATAN STRUKTURAL}

Pope dalam Kurniadi, dkk. (2009: 37) menyebut pertarungan untuk mendapatkan informasi selalu terjadi antara dan orang-orang yang memegang tampuk kekuasaan tetapi enggan membagi kekuasaan tersebut ke rakyat. Pertarungan itu terjadi karena hakekat informasi adalah kekuasaan. Pihak yang mendapatkan informasi akan memiliki kekuatan lebih di banding pihak lainnya.

Sebagai sebuah kekuasaan, kontrol penguasaan atas informasi dapat berpotensi terjadinya penyalahgunaan kekuasaan yang dimiliki. Tertutupnya informasi dalam mekanisme pengisian jabatan publik misalnya, jelas memberangus hak masyarakat yang seharusnya dapat mereka nikmati. Masyarakat kehilangan ruang partisipasinya untuk mengubah model pelayanan publik karena informasi yang tertutup. Dalam penyelenggaraan 
tata kelola pemerintahan yang baik, adanya wujud transparansi adalah satu upaya untuk mencegah beroperasinya patron klien dalam pengisian jabatan publik. Terwujudnya partisipasi aktif akan mendidk masyarakat menjadi paham akan berbagai aktifitas penguasa dalam mengelola pemerintahan. Terlebih lagi mekanisme pengsian jabatan publik akan berpengaruh pada kebijakan bagi hajat hidup masyarakat. Adanya transparansi menjadikan masyarakat memiliki informasi lengkap untuk melakukan pengawasan dan evaluasi tentang segala hal yang tidak berpihak pada kepentingan publik.

Berbicara tentang transparansi dalam pengisian jabatan struktural di lingkungan pemerintah daerah bukan berarti sama sekali tidak ada. Pertanyannya apakah sudah berjalan dengan baik? Dari pengalaman berbagai daerah melalui mekanisme lelang jabatan, nyatanya isu etnisitas masih tetap tumbuh subur. Hal ini dikarenakan proses maupun mekanisme pengisian jabatan tersebut masih pada derajat transparan yang rendah.

Secara umum, jika dikategorikan ada 4 derajat transparansi (Kurniadi, dkk 2009: 42) dengan penjelasan bagan seperti di bawah ini:

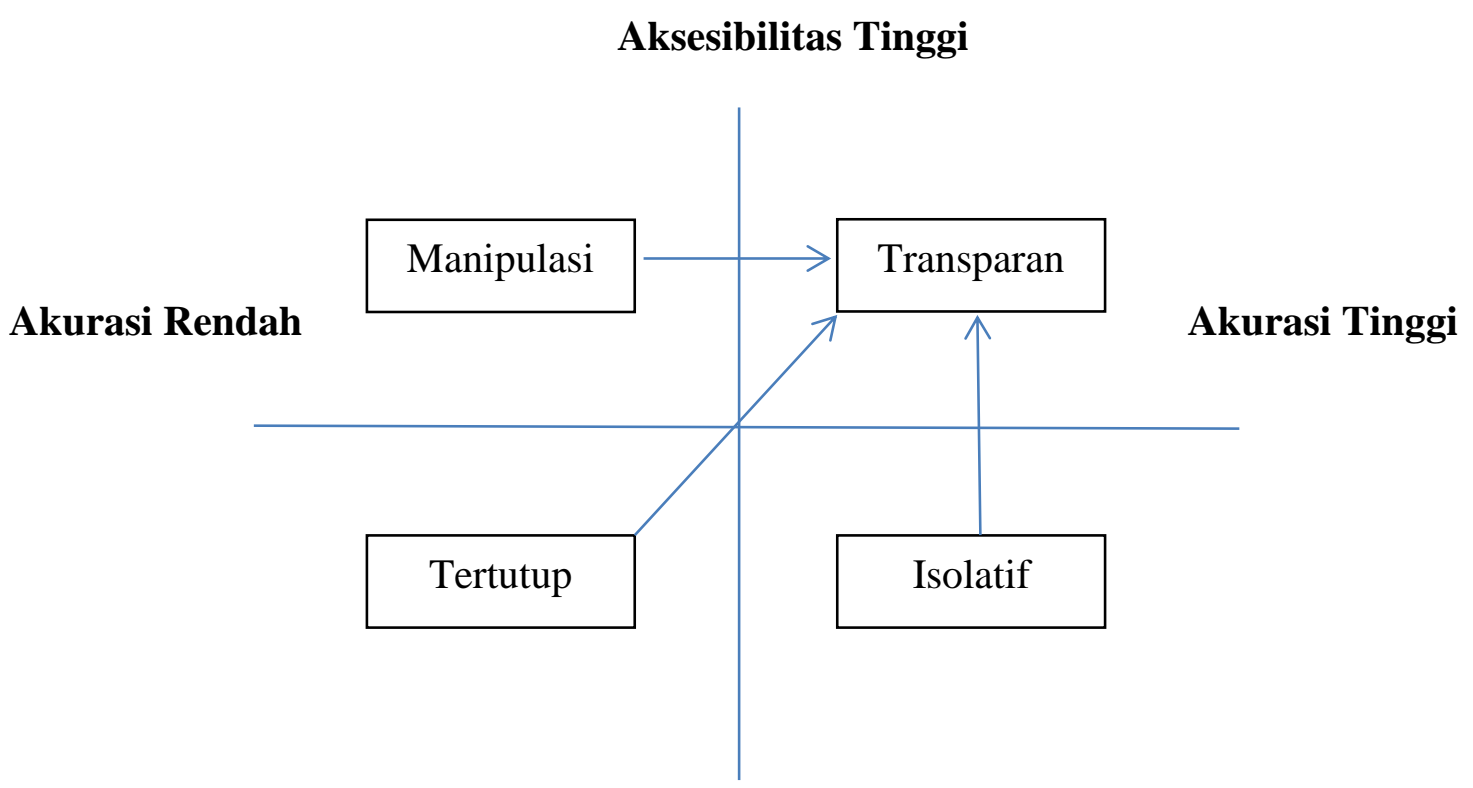

\author{
Aksesibilitas Rendah \\ Gambar 1 Derajat Transparansi \\ Sumber: Monograph on Politics \& Government UGM (2009)
}

Sebagaimana yang dijelaskan di atas, proses menuju transparansi dalam mekanisme pengisian jabatan publik bukanlah suatu proses yang mudah. Ia adalah proses yang panjang, membutuhkan waktu dan terkadang berbiaya tinggi. Namun upaya menuju ke arah 
transparansi birokrasi harus dilakukan karena ada nilai strategis yang mendasarinya, yaitu terciptanya saling percaya antar masyarakat dan birokrasi, sehingga tujuan-tujuan pemerintah dalam memberikan layanan yang baik bagi publik dapat tercapai. Artinya, penerapan prinsip transparansi memiliki kontribusi penting, tidak hanya bagi masyarakat tetapi juga bagi pemerintah sebagai lembaga sekaligus individu-individu yang ada di dalamnya yakni birokrat (Kurniadi, dkk. 2009 : 38).

Selain itu, strategi mewujudkan transparansi dalam mekanisme pengisian jabatan publik juga dilakukan untuk menciptakan hubungan responsif antara pemimpin/elit dan klien/masyarakat yang dimanifestasi melalui sistem tata kelola pemerintahan yang baik. Hubungan responsif ini dibangun dengan kesadaran kognitif masyarakat sebagai warga negara bukan sebagai anggota loyalis etnis semata. Sehingga, akan terwujud partisipasi kritis masyarakat dalam mendorong dan mengawasi kahadiran elit berbasis etnis. Untuk itu, maka diperlukan perubahan paradigma birokrasi yang tak lagi alergi akan transparansi dalam restrukturisasi birokrasi di daerah, khususnya di Kabupaten Muaro Jambi. Alhasil, lahirnya birokrasi yang tanggap dalam mengurusi dan mengontrol isu-isu publik menjadi agenda dari perwujudan transparansi dalam pengisian jabatan struktural di lingkungan pemerintah daerah kabupaten Muaro Jambi.

\section{PEMBAHARUAN PARADIGMA BIROKRASI SECARA PARTISIPATIF: AGENDA BERSAMA}

Kebangkitan politik etnisitas di ranah lokal sebagaimana dijelaskan di atas, tentu saja butuh pencermatan yang lebih serius. Karena kalau tidak, akan terjadi gesekan dan pertentangan yang maha dahsyat untuk di beberapa wilayah Indonesia ke depan. Karena itu, kondisi Indonesia yang plural dari sisi etnisitas menimbulkan pertanyaan dapatkah masyarakat yang multi-etnik ada tanpa konflik yang berarti di kalangan kelompok-kelompok etnis yang berbeda.

Jawaban atas pertanyaan di atas adalah demokrasi konsosiasional. Karena demokrasi konsosiasional menyarankan agar semua aktor yang ada di dalam masyarakat melakukan kerjasama antara etnisitas. Demokrasi konsosiasional mengharapkan berbagai kelompok etnis itu saling merembes secara teritorial dan genetika. Sedangkan menurut Haboddin (2012: 124) dari sudut pandang politik, demokrasi konsosiasional berusaha menciptakan suasana harmonis antar etnis dengan menerapkan dua nilai penting, yakni; Pertama, tidak terdapat 
susunan kelompok hirarkis sehingga tidak ada kelompok yang dominan atau yang mengeksploitir yang lainnya. Kedua, terdapat pembagian kekuasaan politik yang sama dan semua kelompok etnis terwakili secara proporsional di dalam strukur kekuasaan.

Dua nilai yang ditawarkan dalam demokrasi konsosiasional tentu saja membutuhkan prasyarat dan aturan main yang harus ditaati oleh semua komunitas yang begitu plural pembilahan SARA-nya di beberapa lokal. Ada empat prasyarat menurut Lijphart (1997) dalam mempraktekkan demokrasi konsosiasional di ranah lokal. Pertama, kemampuan dan kemauan untuk mengakui bahaya-bahaya instabilitas yang merupakan inheren dalam masyarakat yang tingkat fragmentasi dan polarisasi sosialnya tinggi. Kedua, memerlukan adanya komitmen untuk memelihara nation-state yang ada. Artinya para tokoh masyarakat harus mempunyai keinginan untuk mencegah adanya kemungkinan disintegrasi daerah. Ketiga, ada kemampuan untuk mengangkat persoalan antar etnis masing-masing cleavages ke tingkat yang lebih tinggi. Keempat, ada kemampuan untuk menempa usaha mencari penyelesaian yang tepat guna memenuhi tuntutan dari masing-masing etnis, dengan ditemukannya aturan main yang jelas serta pada tingkat kelembagaan yang tepat.

Aturan main merupakan hal yang sangat esensial dalam demokrasi konsosiasional. Adapun aturan mainnya mencakup: Politics is not a game, it is a business. Artinya proses politik hendaknya ditujukan untuk mencapai hasil, bukan untuk melihat siapa yang kalah dan yang menang; Agree to disagree. Untuk itu, peranan birokrasi di sini adalah menemukan persamaan supaya tercapai kompromi; Proportionality. Artinya keberadaan etnis bukan lagi menjadi objek politisasi melainkan akan memperoleh porsi kekuasaan dan konsekuensikonsekuensinya sesuai dengan proporsi kekuatan yang dimiliki.

Adalah sebuah keniscayaan Pilkada merupakan kompetisi politik di tengah masyarakat. Persaingan kelompok dalam memperebutkan posisi kepala daerah tentu harus mencerminkan interaksi kelompok sosialnya. Strategi masing-masing kelompok tentu dengan sendirinya mencerminkan perbedaan orientasi basis sosial pendukung. Hubungan elit birokrat dan basis sosial keetnisan sangat wajar terjadi ketika partai belum berhasil melakukan institusionalisasi organisasi di masyarakat.

Hubungan sosial antara massa pendukung dan pemimpin di pemerintahan lokal seharusnya tidak tercipta dalam kontestasi politik, namun sudah menjadi kewajiban bagi kepala daerah bersama mesin birokrasinya yang melakukan agitasi untuk memastikan 
terpenuhinya janji-janji politik yang dikampanyekan dalam masa pertarungan politik. Kondisi tersebut, semestinya dapat dikonstruksi untuk peningkatan kesejahteraan masyarakat melalui kendali terhadap isu-isu publik yang berkaitan langsung dengan hajat hidup masyarakat, termasuk misalnya partisipasinya dalam menentukan elit-elit birokrat di level lokal. Peran birokrat yang memiliki hubungan emosional dan sosiologis dengan warga menjadi aktor dominan dalam menggerakan masa untuk mempengaruhi pemenuhan dan pengembangan urusan publik. Keberadaan aktor dominan yang berasal dari elit birokrat menunjukkan bahwa praktik informal dapat menjadi strategi mendorong lahirnya kebijakan publik yang mengakomodasi hak-hak warganya.

Terlepas dari ruang perebuatan kekuasaan antar etnis, kehadiran media digital baru menyebabkan terjadinya perluasan ruang publik politik. Media sosial digital misalnya, telah mentransformasikan kesadaran politik personal ke ruang publik baru yang terbuka secara interaktif. Media baru ini memberikan struktur kesempatan yang berpotensi memperbaharui minat dan kepentingan pada partisipasi warga. Untuk itu, kapasitas informasi yang disediakan oleh media digital baru tersebut memungkinkan warga menjadi lebih memiliki pengetahuan tentang isu-isu politik dan birokrasi. Sementara, tingkat interaktif media memungkinkan munculnya bentuk-bentuk baru komunikasi antara warga dan pejabat terpilih (Hamid 2014: 736). Jika dikelola dengan baik, maka tidak menutup kemungkinan bahwa potensi penggunaan media digital baru dalam bentuk apapaun akan memiliki pengaruh yang besar dalam mengelola nilai-nilai kebaikan bersama pada masa mendatang.

Jadi, agar proporsionalitas etnisitas dalam postur birokrasi di muaro Jambi dapat terwujud maka partisipasi masyarakat menjadi strategi jitu yang bisa digunakan. Mengingat Dahl (1978) dalam Pabottingi (2014: 361) mengatakan; Demokrasi mengandaikan partisipasi dan ruang publik sebagai elemen dasar yang tidak dapat dihindari. Keterlibatan atau partisipasi publik dalam hal ini warga Muaro Jambi niscaya menjadi legitimasi bagi penyelenggaraan birokrasi dalam memberikan dan memperbaiki pelayanan publik agar terus memperbaiki dan makin berkualitas dari waktu ke waktu. Hal ini menjadi jaminan tercapainya kesejahteraan warga.

Sebagai legitimasi penyelenggaraan pemerinahan, partisipasi dapat memberikan kepastian bahwa interaksi patron klien dalam birokrasi pasca pilkada dapat diputus. Dalam analisis James Scott hubungan patron-klien memiliki beberapa ciri pokok yang membedakan 
dengan hubungan sosial lainnya (Putra, 1988: 3-5). Pertama, terdapat ketidaksamaan dalam pertukaran. Kedua, adanya tatap muka, dimana kedekatan pribadi ada di dalamnya. Ketiga, sifat yang luwes dan meluas.

Dengan menghadirkan partisiapasi masyarakat dalam proses pengisisan jabatan struktural di birokrasi misalnya, ciri-ciri patron klien yang tumbuh akan dengan mudah bisa diuraikan. Ciri pertama adalah ketidaksamaan dalam pertukaran, ketidakseimbangan kedudukan akan menjadi tidak mencolok. Dengan adanya keterlibatan masyarakat dalam proses pengisian jabatan publik, artinya segala ketimpangan kedudukan agar selalu sama dapat diciptakan melalui sistem saling mengawasi dan mengevaluasi. Dengan begitu, secara kedudukan antara elit dari etnis Jawa ataupun lainnya dengan kelomposk etnsisitasnya memiliki kedudukan seimbang dalam proses penyelenggaraan pemerintahan.

Kedua, sebuah bentuk hubungan pribadi. Sifat ini juga bisa dikatakan akan semakin hilang dalam hubungan kemasyarakatan di Muaro Jambi. Program pelibatan masyarakat dalam proses pengisian jabatan publik melalui media digital baru dapat menghasilkan hubungan sosial di Muaro Jambi yang bukan semata-mata lagi untuk menjaga eksistensi kekerabatan yang terjalin, melainkan lebih sebagai respon kebutuhan masyarkat Muaro Jambi agar mendapatkan kepastian pelayanan publik yang baik dan kesejahteraan yang merata. Atinya, ke depan birokrasi sebagai mesin pemerintah daerah dipaksa untuk memiliki respon terhadap kehidupan sosial di tengah masyarakat, bukan untuk kepentingan kepala daerah terpilih. Ciri ketiga terkait kekerabatan. Dengan menggunakan media digital baru dalam pengisian jabatan di lingkungan pemerintah daerah maka diharapkan seorang kepala daerah terpilih tidak lagi bisa membawa kerabatnya dari etnis tertentu untuk menjadi kepala dinas atau posisi strategis lainnya. Mengingat, transparansi dan partisipasi aktif masyarakat dalam proses pengisian jabatan publik akan mengarahkan pada hubungan yang profesional antara kepala daerah terpilih dan elit birokrasi. Dengan begitu, makna netralitas dan profesionalitas birokrasi benar-benar sebagai orientasi pembangunan politik pasca pilkada.

\section{KESIMPULAN}

Instrumentasi etnis dimainkan dalam banyak ruang kontestasi politik di ranah lokal. Hal ini sudah barang tentu dikarenakan ketidaksiapan elit lokal dalam mengelola transisi menuju demokrasi yang substantif. Lemahnya kesadaran elit dalam memahami dan memposisikan etnisitas ke dalam realitas kontestasi politik berimbas pada adanya politisasi 
birokrasi berbasi primordial. Padahal, cukup dengan sumber daya sosial, elit lokal akan memiliki kemampuan dalam mempengaruhi masa.

Belajar dari pengalaman banyak daerah dan Muaro Jambi khususunya, idealnya model kepemimpinan di era revolusi industri 4.0 harus menjadi pendobrak dan pencipta perubahan. Pemimpin generasi baru ini harus menajadi pendobrak tradisi dalam mekanisme pengisian jabatan publik di pemerintah daerah. Maka perlu perangkat khusus untuk pembagian kekuasaan antar etnis di dalam birokrasi. Alhasil, transparansi informasi dalam mekanisme pengisian jabatan struktural serta partisipasi aktif masyarakat melalui media digital baru menjadi jalan ideal bagi masyarakat untuk menjauhkan birokrasi dari politik. Hal ini dilakukan agar restrukturisasi birokrasi pasca pilkada tidak lagi berbau nepotisme, akan tetapi memberi makna bagi kesejahteraan rakyat.

Sebagai sebuah perangkat baru yang terbuka bagi pergulatan itu, media digital baru telah menjadi sebuah solusi yang menyimpan potensi penting. Tegasnya, mengutip Rorty dalam Hamid (2014: 745) apabila media digital digunakan dengan tepat untuk meningkatkan apa yang disebut "partisipasi bebas dalam deliberasi demokrasi”, maka kecanggihan yang demikian akan membentuk kemajuan yang positif. Netralitas dan profesionalisme birokrasi menjadi relevan untuk dicapai.

\section{DAFTAR PUSTAKA}

Abdilah, U. (2002). Politik Identitas Etnis "Pergulatan Tanda Tanpa Identitas". Magelang: INDONESIATERA.

Alo Liliweri, M. (2005). Prasangka dan Konflik "Komunikasi Lintas Budaya Masyarakat Multikultur". Yogyakarta: LKiS.

Ardianto, dkk. (2009).Memutus Interaksi Patron-Klien di Lingkungan Perkebunan. Monograph on Politics \& Government. Vol.3. No.2.

Dwiyanto, Agus. (2002). Reformasi Birokrasi Publik di Indonesia. Yogyakarta: PSKK UGM

Dwiyanto, Agus. (2003). Reformasi Tata Pemerintahan dan Otonomi Daerah. Yogyakarta: PSKK UGM

Haboddin, Muhtar (2012). Menguatnya Politik Identitas di Ranah Lokal. Jurnal Studi Pemerintahan. Vol. 3. No.1 Edisi Februari. 
Jambi Ekspres. (2016). Adu Strategi di Bumi Sailun Salimbai, Libatkan Sejumlah Tokoh dan Nama Besar. 07 Oktober : hlm. 11.

Jumiarti, Titik. (2010). Peran Budaya Birokrasi dalam pengembangan Tat Kelola Pemerintahan Yang Baik. Jurnal politik. Vol.1. No 2 Edisi Oktober.

Kurniadi, dkk. (2009). Menuju Bekerjanya Tata Pemerintahan Lokal Yang Baik: Partisipasi, Transparansi, dan Akuntabilitas. Monograph on Politics \& Government. Vol.3. No.1

Media Indonesia. (2018). MPR dukung Pilkada dikembalikan ke DPRD. 10 April: hlm.3.

Nordholt, H.S \& Klinken, G.V. (2007). Politik Lokal di Indonesia. Jakarta: Yayasan Obor Indonesia. KITLV.

Priyono, AE \& Hamid. (2014). Merancang Arah Baru Demokrasi. Jakarta: KPG

Putra, Heddy Shri Ahimsa. (1988). Minawang: Hubungan Patron Klien di Sulawesi Selatan. Yogyakarta: Gadjah Mada Press

Thoha, M. (2002). Perspektf Perilaku Birokrasi. Jakarta: PT Raja Grafindo Persada.

Thoha, M. (2010). Birokrasi \& Politik di Indonesia. Jakarta: Rajawali Pers.

Thoha, M. (2011). Birokrasi Pemerintah Indonesia Di Era Reformasi. Jakarta: Kencana.

Tjokrowinoto, Moeljarto. (2001). Birokrasi dalam Polemik. Yogyakarta: Pustaka Pelajar 